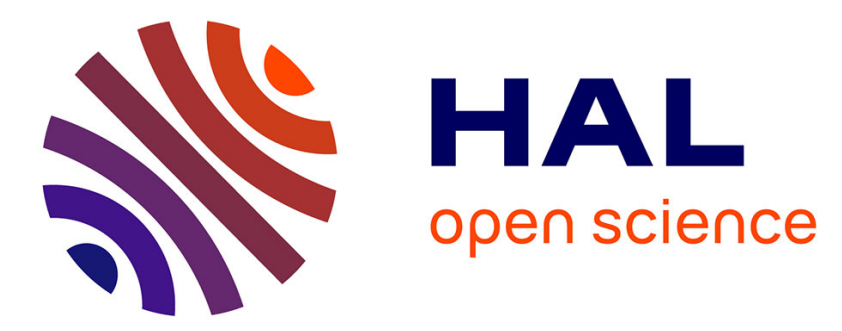

\title{
Purification and biological characterization of chinook salmon prolactin
}

\author{
Patrick Prunet, Louis L. Houdebine
}

\section{To cite this version:}

Patrick Prunet, Louis L. Houdebine. Purification and biological characterization of chinook salmon prolactin. General and Comparative Endocrinology, 1984, 53, pp.49-57. 10.1016/0016-6480(84)902235. hal-02728615

\section{HAL Id: hal-02728615 \\ https://hal.inrae.fr/hal-02728615}

Submitted on 2 Jun 2020

HAL is a multi-disciplinary open access archive for the deposit and dissemination of scientific research documents, whether they are published or not. The documents may come from teaching and research institutions in France or abroad, or from public or private research centers.
L'archive ouverte pluridisciplinaire HAL, est destinée au dépôt et à la diffusion de documents scientifiques de niveau recherche, publiés ou non, émanant des établissements d'enseignement et de recherche français ou étrangers, des laboratoires publics ou privés.

\section{다(1)(2)}

Distributed under a Creative Commons Attribution - ShareAlikel 4.0 International 


\title{
Purification and Biological Characterization of Chinook Salmon Prolactin
}

\author{
Patrick Prunet* and Louis-Marie Houdebine ${ }^{\dagger}$ \\ *Laboratoire de Physiologie des Poissons, INRA, Campus de Beaulieu, 35042 Rennes, France, \\ and Department of Zoology and Cancer Research Laboratory, University of California, \\ Berkeley, California 94720; and †Laboratoire de Physiologie de la Lactation, Institut National de la \\ Recherche Agronomique, CNRZ, 78350 Jouy-en-Josas, France
}

Accepted December 9, 1982

\begin{abstract}
Prolactin from chinook salmon pituitaries was purified by acid acetone extraction, saline precipitation, chromatofocusing, and gel filtration. This procedure allowed us to recover highly purified prolactin as demonstrated by the presence of a single $\mathrm{NH}_{2}$-terminal amino acid and a single band in sodium dodecyl sulfate gel electrophoresis. Chinook salmon prolactin appeared to be a basic protein of 22,500 molecular weight. Throughout the purification, prolactin bioactivity was followed by radioreceptor assay for lactogenic hormones, The prolactin character of the purified protein was established by its lactogenic activity in the rabbit mammary gland in vitro and its sodium-retaining activity in hypophysectomized Fundulus heteroclitus.
\end{abstract}

It is now well established that the teleost pituitary contains a protein which is similar to mammalian prolactin and which is endowed with osmoregulatory activity (see reviews by Ensor, 1979; Clarke and Bern, 1980). Teleost prolactin is devoid of lactogenic activity as judged by the pigeon crop sac and mousc mammary gland bioassays (Nicoll et al., 1966; Nicoll and Bern, 1968; Doneen, 1976; Farmer et al., 1977). However, Prunet et al. (1979) and Houdebine et al. (1981) have recently observed that salmon and tilapia prolactins can induce casein synthesis in rabbit mammary gland in culture. These findings suggest that the lactogenic activity expressed in the rabbit and osmoregulatory activity expressed in various euryhaline teleosts may be two properties of teleostean prolactin. In a previous study (Prunet et al., 1979), partial purification of chinook salmon was carried out using the radioreceptor assay for lactogenic hormone as a test. In this communication we discuss the purification and the characterization of prolactin from chinook salmon (Oncorhynchus tschawytsicha). To detect prolactin activity the radioreceptor assay was used throughout the purification. The final product exhibited the lactogenic activity previously observed in the partially purified fractions (Prunet et al., 1979). In addition, the purified hormone proved to have an osmoregulatory activity as judged by the Fundulus bioassay (see Grau et al., 1983).

\section{MATERIALS AND METHODS}

\section{Hormone Isolation}

Salmon pituitary collection. Pituitary glands from female and male chinook salmon $(O$. tschawytscha) which had been in freshwater for several weeks at the Spring Creek National Fish Hatchery (Underwood, Wash.) were collected following decapitation and were immediately frozen in liquid nitrogen and lyophilized.

Osmoregulatory activity. The sodium-retaining activity of this hormone was assessed in hypophysectomized Fundulus heteroclitus transferred in freshwater according to the techniques of Grau et al. (1983).

\section{Biochemical Analysis}

Several analytical electrophoresis systems were used during this purification. Anionic electrophoresis at $\mathrm{pH} 9.3$ was performed in discontinuous polyacrylamide gel 
with a spacer gel of $3 \%$ acrylamide and a running gel of $7.5 \%$ (Maurer, 1968). Cationic electrophoresis at $\mathrm{pH} 4.5$ was performed on $15 \%$ acrylamide gel according to the method of Riesfeld et al. (1962). Electrophoresis in the presence of sodium dodecyl sulfate (SDS) was done according to Weber and Osborn (1969). In all cases proteins were stained with $0.2 \%(w / v)$ Coomassie blue in $50 \%$ methanol solution and destained overnight in $7 \%$ acetic acid. Using these analytical techniques purified chinook salmon prolactin was compared with chum salmon prolactin purified by $\mathrm{Ka}-$ wauchi et al. (1983) and with homogenate of rostral pars distalis from coho salmon pituitaries.

To evaluate the purity of the final salmon prolactin preparation, $200 \mu \mathrm{g}$ of this material was submitted to $\mathrm{NH}_{2}$-terminal analysis by the dansyl procedure (Gray 1967; Woods and Wang, 1967). The amino acid composition was determined by the method of Spackman et al. (1958) using an automatic amino acid analyzer. These analyses were performed by Professor H. Papkoff (Hormone Research Laboratory, University of California, San Francisco).

The electrofocusing experiment was monitored on a flat-bed FBE 1000 (Pharmacia). The agarose gel (1\%) with a volume of $28 \mathrm{ml}$ contained Biolyte ampholytes $(2 \%$, $\mathrm{v} / \mathrm{v}$ ) in the $\mathrm{pH}$ range $8-10$. The cathode and anode solutions were, respectively, $1 \mathrm{~N}$ $\mathrm{NaOH}$ and $0.2 M$ histidine. Following $1 \mathrm{hr}$ of prefocusing at $5 \mathrm{~W}$, the material was focused for $3 \mathrm{~h}$ at $5 \mathrm{~W}$.

First purification protocol tested (Idler et al., 1978; Ng et al., 1981). The alkaline extract from $10 \mathrm{~g}$ of lyophilized pituitary glands, using 0.05 $M$ Tris- $\mathrm{HCl}, \mathrm{pH} 9.5,0.5$ $M \mathrm{NaCl}$ buffer, was chromatographed on concanavalin A-Sepharose (Pharmacia) in two successive runs. The nonglycoprotein material flowing through was layered on an Ultrogel AcA 54 (IBF) column (Pharmacia $\mathrm{K}$ 50-100). The bioactive proteins corresponding to a molecular weight of 22,000 were rechromatographed on the same gel. The resulting enriched prolactin fraction was subjected to ion-exchange chromatography (DEAE Bio-Gel A (Biorad)-equilibrated with $0.005 M$ Tris- $\mathrm{HCl}, \mathrm{pH} 9.5$ ). The nonabsorbed material which contained prolactin was submitted to a final gel filtration using Sephadex G-75 in $0.05 \mathrm{M}$ $\mathrm{NH}_{4} \mathrm{HCO}_{3}$ and the resulting fractions obtained were lyophilized.

Second purification protocol. This protocol followed initial acid acetone extraction indicated by Kawauchi et al. (1983). The acid acctone powder thus obtained was dissolved in water at $\mathrm{pH} 2.5$ and $\mathrm{NaCl}$ was added to a final concentration of $10 \% \mathrm{NaCl}$ saturation (Cole and Li, 1955; Kawauchi and Tubokama, 1979). The solution was stirred for $12 \mathrm{hr}$ at $4^{\circ}$ and centrifuged for 1 hr at $100,000 \mathrm{~g}$. The resulting supernatant was dialyzed against distilled water and lyophilized. This fraction was then layered on a Polybuffer exchanger gel, PBE 94 (Pharmacia), equilibrated with $0.025 M$ ethanolamine- $\mathrm{HCl}, \mathrm{pH} 10.2$. The elution was carried out with a linear $\mathrm{pH}$ gradient using $0.025 M$ ethanolamine- $\mathrm{HCl}$ buffer from $\mathrm{pH}$ 10.2 to $\mathrm{pH}$ 9.3. After dialysis and lyophilization the bioactive fraction was submitted to a final gel filtration on Sephadex G-50 in $0.05 \mathrm{M} \mathrm{NH}_{4} \mathrm{HCO}_{3}$. The fraction containing prolactin was then lyophilized.

\section{Bioassays}

Radioreceptor assay. The presence of salmon prolactin activity during purification was determined using a radioreceptor assay for lactogenic hormone initially proposed by Shiu et al. (1973) and also used for fish hormone (Prunet et al., 1977, 1979). The lack of parallelism between the displacement curves generated with ovine prolactin and with the salmon prolactin-containing fractions in the presence of ${ }^{125} \mathrm{I}-\mathrm{la}$ beled ovine prolactin renders uneasy an accurate appreciation of the fish prolactin concentration. For the sake of convenience, the biological activity ( $\mu \mathrm{g}$ of ovine prolactin/mg of protein) of each sample was estimated by finding the yield of the ovine prolactin concentration and the sample protein concentration, calculated by the displacement curves and both inhibiting $50 \%$ of the ${ }^{125}$ I-labeled ovine prolactin binding. 
Lactogenic activity. The lactogenic activity was evaluated by estimating its capacity to induce casein synthesis in rabbit mammary explants. The culture technique was similar to that presented in previous reports (Prunet et al., 1979; Houdebine et al., 1981). The ovine prolactin was the generous gift of the $\mathrm{Na}$ tional Institutes of Health (NIH-P-S13). One major difference has been introduced in the estimation of casein synthesis. Instead of measuring the capacity of the tissue to incorporate labeled amino acids into casein, the content of the explant in $\beta$-casein was evaluated using a radioimmunoassay. Rabbit $\beta$-casein was purified by two successive chromatographies on DEAEcellulose (Testud and Ribadeau-Dumas, 1973), Antirabbit $\beta$-casein was obtained in goat, and anti-goat immunoglobulin was obtained in rabbit. After a culture of 1 day in the presence of ovine prolactin or salmon prolactin, the explants (50 mg of tissue) were homogenized in $4 \mathrm{ml}$ of $0.14 \mathrm{M} \mathrm{NaCl}, 0.01 \mathrm{M}$ sodium phosphate $(\mathrm{pH} 7.6)$, and $0.1 \%$ Triton $X-100$. To $50 \mu \mathrm{l}$ of the $5000 \mathrm{~g}$ supernatant $30,000 \mathrm{cpm}{ }^{125}$ I-labeled $\beta$-casein, labeled by a chloramine- $T$ procedure, at a specific activity of $50-75 \mu \mathrm{Cl} / \mu \mathrm{g}$ and $200 \mu \mathrm{l}$ of the goat anti $+\beta$ casein serum, diluted 2000 -fold, were added. The final volume was adjusted to $600 \mu \mathrm{l}$ with phosphate buffer. After 24 hr at room temperature, $200 \mu \mathrm{l}$ of a 5 -fold diluted rabbit serum containing anti-goat immunoglobulin antibodies was added to the incubate and the mixture was further incubated for 24 hr al room temperature. The immunoprecipitate was sedimented at $2200 \mathrm{~g}$ and the radioactivity of the pellet was measured with a gamma counter.

\section{RESULTS}

\section{Isolation of the Hormone}

The first purification procedure led to a fractionation similar to that described previously by Idler et al. (1978). Chinook salmon prolactin, which was not retained on concanavalin A-Sepharose, eluted from gel filtration às a protein having a molecular weight of 22,000 . Moreover, this protein was not retained on DEAE-ionic exchanger at $\mathrm{pH} 9$ and low salt concentration $(0.005$ $M$ Tris-HCl). However, the prolactin preparation thus obtained did not seem to be pure as indicated by the asymetric peak obtained after Sephadex G-75 gel filtration (data not shown). The low recovery of prolactin material ( $4 \mathrm{mg}$ ) after this gel filtration chromatography did not allow an additional chromatography step. The heterogeneity of the prolactin fraction obtained was confirmed by the presence of several $\mathrm{N}$-terminal amino acids and by the presence of four bands in the electrophoresis trial performed at $\mathrm{pH} 4.5$ (the main band having a $R_{f}=0.5$ ) and that performed in the presence of SDS (Prunet, 1981). Moreover, this preparation did not give any clear band after an electrophoresis at $\mathrm{pH}$ 9.3. A preliminary study of this material using electrofocusing techniques confirmed the basic $\mathrm{p} I$ of this protein $(\mathrm{p} I>8)$. These problems led us to question whether the saline and alkaline extraction procedure was suitable for this purification.

The second protocol based on acid acetone extraction gave rise to a recovery of $335 \mathrm{mg}$ of powder from $5 \mathrm{~g}$ of lyophilized pituitaries. After saline precipitation at $\mathrm{pH}$ $2.5,96 \%$ of the prolactin activity detected by the radioreceptor assay remained in the supernatant (Table 1). This crude prolactin preparation $(80 \mathrm{mg}$ ) was layered on a chromatofocusing gel. The linear $\mathrm{pH}$ gradient eluted the proteins having $\mathrm{p} r$ 's between 9 and 10 . To obtain the $\mathrm{pH}$ gradient described under Materials and Methods, the Polybuffer (PBE) 94 recommended by Pharmacia was replaced by a $0.025 M$ ethanolamine-HCl buffer. These conditions led to a good recovery of proteins from the eluted fractions, a problem which proved to be difficult to solve in the presence of Polybuffer. About $87 \%$ of the prolactin activity was concentrated in the $\mathrm{Fb}$ fraction (Fig. 1). Chromatography on Sephadex G50 of this fraction led to separate the prolactin activity (first symetric peak) from smaller contaminants (Fig. 2). The prolactin preparation thus obtained was further demonstrated to be pure. Surprisingly, this chromatography step did not increase the biological activity measured in the radioreceptor assay of the prolactin preparation (Table 1). This might be due to the low yield of this gel filtration experiment. Such a low recovery of material has been observed pre viously when very low quantities of pro- 
TABLE 1

Chinook Salmon Prolactin Activity Estimated in the Radioreceptor Assay for Lactogenic Hormone

\begin{tabular}{ccc}
\hline Sample & $\begin{array}{c}\text { Biological activity } \\
(\mu \mathrm{g} \text { ovine prolactin/mg } \\
\text { protein) }\end{array}$ & $\begin{array}{c}\text { Amount of ovine } \\
\text { prolactin equivalent } \\
(\mu \mathrm{g})\end{array}$ \\
\hline $\begin{array}{c}\text { Crude pituitary extract } \\
\text { Acid acetone powder }\end{array}$ & 0.30 & 521 \\
$\begin{array}{c}\text { Supernatant from } \\
\text { saline precipitation }\end{array}$ & 0.75 & 190 \\
2e Chromatofocusing & 1.61 & 128 \\
$\quad$ fraction (Fb) & 7.43 & 63 \\
3e Chromatofocusing & & \\
fraction (Fc) & 4.86 & 10 \\
Gel filtration (the peak) & 7.2 & 26 \\
\hline
\end{tabular}

Note. The displacement curves obtained in the radioreceptor assay for each fish sample and for ovine prolactin are made linear by log-logit transformation. The biological activity of the different fractions is expressed in ovine prolactin equivalent per milligram of protein (for details see Material and Methods). Amount of ovine prolactin equivalent is obtained after multiplying the biological activity by the protein amount of the fraction.

teins (a few milligrams) are layered on wt tissue. The purity of the prolactin prepthe gel. aration was assessed by the existence of a

\section{Chemical and Physical Characterization}

The amount of final purified prolactin corresponds approximately to $70 \mathrm{mg} / \mathrm{kg}$ wet single $\mathrm{NH}_{2}$-terminal amino acid (leucine). Electrophoresis in the presence of SDS revealed a single band corresponding to a molecular weight of $22,500 \pm 2000$. Electro-

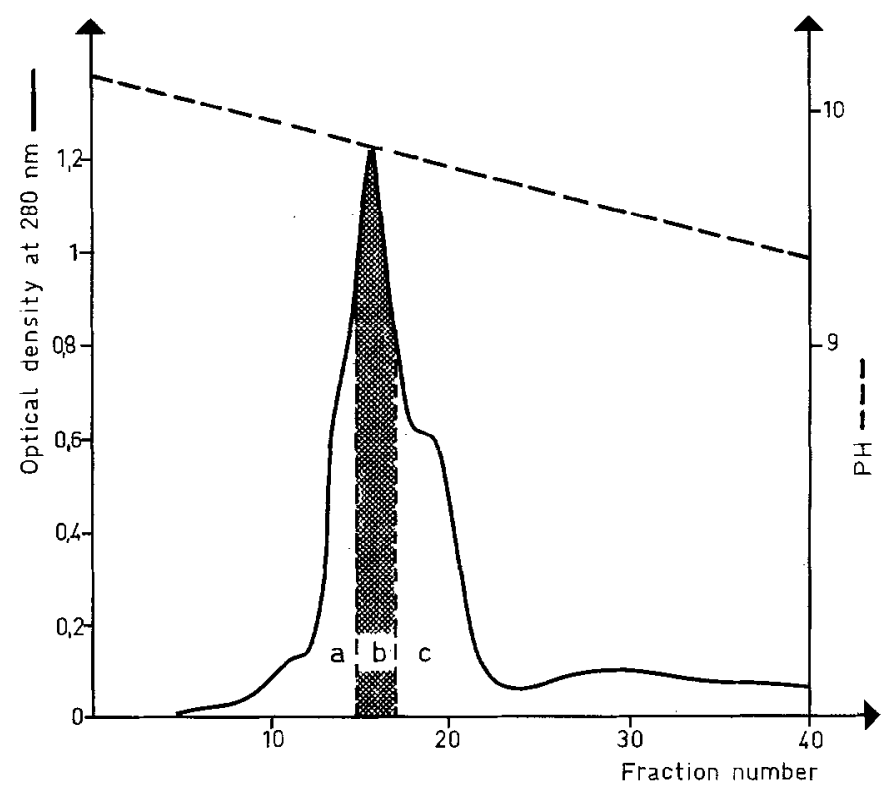

FIG. 1. Chromatofocusing. The supernatant of the saline precipitation was applied to a $1.5 \times 30$ cm column containing PBE 94 gel (Pharmacia) equilibrated with $0.025 \mathrm{M}$ ethanolamine-HCl, $\mathrm{pH} 10.2$. Elution was performed with a linear gradient of $0.025 \mathrm{M}$ ethanolamine- $\mathrm{HCl}$ buffer ranging from $\mathrm{pH}$ 10.2 to 9.3 (fraction size: $2 \mathrm{ml}$; elution rate: $20 \mathrm{ml} / \mathrm{hr}$ ). The peak thus obtained was divided into three fractions $(\mathrm{Fa}, \mathrm{Fb}, \mathrm{Fc})$. 


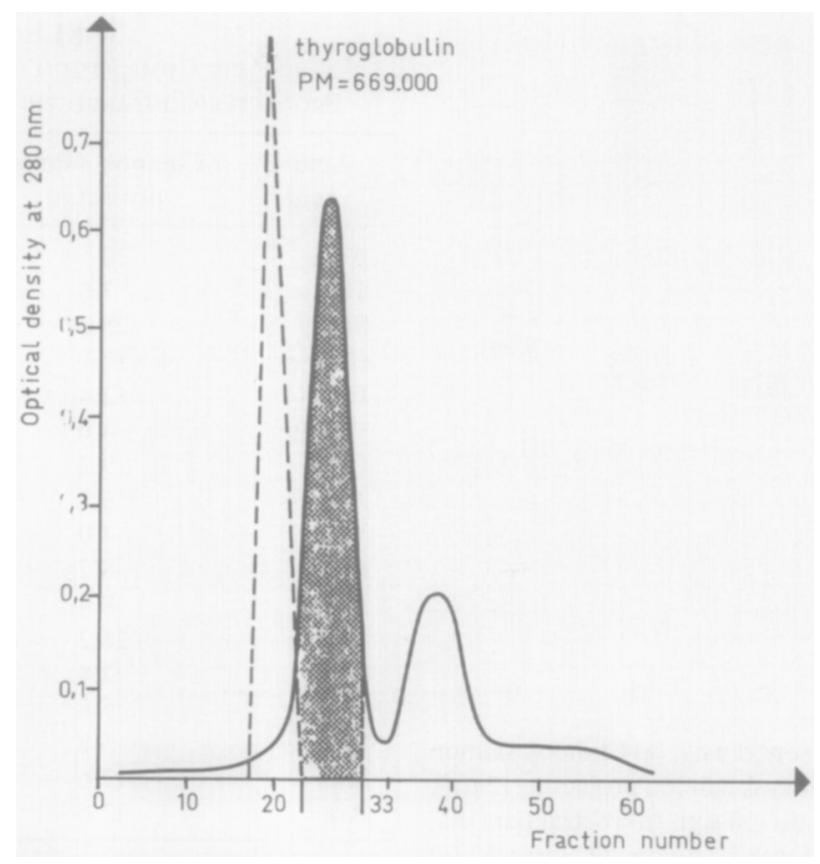

Fig. 2. Gel filtration. Fraction $\mathrm{Fb}(6 \mathrm{mg})$ was layered on a $1 \times 60-\mathrm{cm}$ column of Sephadcx G-50 gcl (Pharmacia). Elution was performed with $0.05 \mathrm{M} \mathrm{NH}_{4} \mathrm{HCO}_{3}$ (elution rate: $5.2 \mathrm{ml} / \mathrm{hr}$; size fraction: 0.6 mil). The void volume of the column was determined with thyroglobulin (dashed line). Prolactin activity was concentrated in the first symmetrical peak.

phoresis of the rostral pars distalis of coho salmon pituitary glands revealed the existence of a major protein running at the same position as the purificd chinook salmon prolactin (Fig. 3) and the prolactin fraction obtained using the first purification protocol: this band appeared to have sodiumretaining activity in hypophysectomized $F$. heteroclitus, a biological property which is specific to prolactin (Grau et al., 1983). Moreover, chum salmon prolactin kindly provided by Professor $\mathrm{H}$. Kawauchi of Kitasato University also gave the same electrophoresis pattern as our chinook salmon prolactin (Fig. 3). When electrophoresis was performed at $\mathrm{pH} 4.5$, essentially a single major band appeared $\left(R_{f}=0.5\right)$ with a second band of lower intensity running immediately behind (Fig. 3).

The $\mathrm{p} I$ of chinook prolactin determined by electrofocusing analysis confirmed its basic value $(\mathrm{p} I=9.4)$.

The comparison of the amino acid composition of chinook prolactin with tilapia prolactin indicated that the former has a lower content of glutamine and glutamic acid and a higher content of lysine and arginine than the latter (Table 2). This finding is compatible with the high $\mathrm{p} I$ of chinook salmon prolactin. Except for alanine and valine which were higher in Tilapia prolactin, the number of other residues was similar for both hormones.

\section{Biological Properties}

Lactogenic activity. Throughout the purification, prolactin bioactivity estimated by the radioreceptor assay progressively increased. The purified chinook salmon prolactin was estimated to be 24 -fold mone potent than the crude pituitary extract (Table 1). However, considering the heterologous nature of this assay, such biological quantification should be viewed with some caution.

It seemed necessary therefore to confirm the lactogenic activity of the pure hormone in the mammary gland culture system. Sev- 


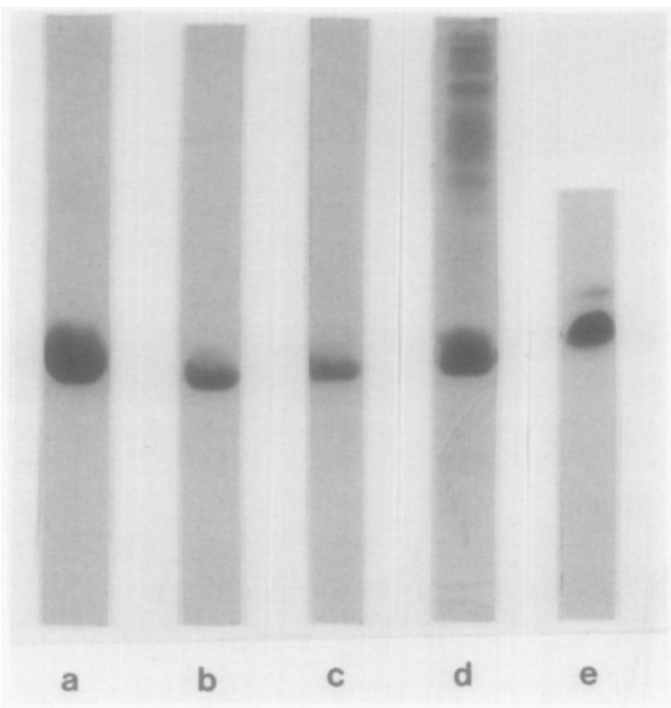

FIG. 3. Slab gel electrophoresis. (a) Chinook salmon prolactin $(40 \mu \mathrm{g})$, (b) chinook salmon prolactin (12 $\mu \mathrm{g})$, (c) chum salmon prolactin $(10 \mu \mathrm{g})$, (d) rostral pars distalis from pituitaries of coho salmon, $O$. kisutch, (e) chinook salmon prolactin $(15 \mu \mathrm{g})$ at $\mathrm{pH} 4.5$. In all cases, the concentration of acrylamide gel was $15 \%$. Electrophoresis of a-d was performed in the presence of SDS whereas e was carried out at $\mathrm{pH} 4.5$ in the absence of the detergent.

eral concentrations of ovine or chinook salmon prolactin were added to the culture medium of rabbit mammary explants. Figure 4 indicates that the maximum response was obtained between 100 and 1000 $\mathrm{ng} / \mathrm{ml}$ ovine prolactin with reduced responses at higher concentrations. This result is in agreement with previous experiments (Houdebine et al., 1981; Djiane et $a l ., 1982)$. Thus it may be concluded that evaluation of lactogenic activity of prolactin can be evaluated equally well by measuring either the biosynthesis of total casein (the previous method) or the accumulation of casein. The purified chinook salmon prolactin exhibited a clear lactogenic activity which was roughly 20 times lower than the activity of ovine prolactin.

Osmoregulatory activity. In the Fundulus bioassay, depicted by Grau et al. (1983), chinook salmon prolactin showed maximum activity for injected dose as low
TABLE 2

Amino Acid Composition of Chinook SaLmon Prolactin Compared to Tilapia Prolactin

\begin{tabular}{lcc}
\hline $\begin{array}{c}\text { Amino } \\
\text { acid }\end{array}$ & $\begin{array}{c}\text { Chinook salmon } \\
\text { prolactin }^{a}\end{array}$ & $\begin{array}{c}\text { Tilapia } \\
\text { prolactin }^{b}\end{array}$ \\
\hline Asp & 20 & 16.4 \\
Thr & 7.6 & 9.4 \\
Ser & 25.0 & 21.6 \\
Glu & 12.2 & 17.4 \\
Pro & 12.4 & 10.8 \\
1/2 Cys & 4.0 & 4.2 \\
Gly & 9.3 & 8.1 \\
Ala & 6.2 & 9.6 \\
Val & 4.0 & 6.8 \\
Met & 8.7 & 5.4 \\
Ile & 8.4 & 9.3 \\
Leu & 26.2 & 24.5 \\
Tyr & 2.4 & 3 \\
Phe & 5.8 & 4.7 \\
His & 5.8 & 4.9 \\
Lys & 12.6 & 8.9 \\
Arg & 12.6 & 6.8 \\
\hline
\end{tabular}

Note. Hydrolysis: $5-7 \mathrm{~N} \mathrm{HCl}, 105^{\circ}, 20 \mathrm{hr}$ (data from Professor H. Papkoff).

${ }^{a}$ Calculated on the basis of a molecular weight of 22,500 .

${ }^{b}$ Taken from Farmer et al. (1977).

${ }^{c}$ Determined from performic acid-oxidized sample as cysteic acid and methionine sulfate.

as $4 \mathrm{ng} / \mathrm{ml}$; thus our chinook prolactin preparation appeared to be approximately 100 times more potent than ovine prolactin.

\section{DISCUSSION}

Chinook salmon prolactin has been obtained in a highly purified form as judged by the presence of a single $\mathrm{NH}_{2}$-terminal amino acid and by its migration as a single band in electrophoresis in presence of SDS. The prolactin character of this purified material was established by its lactogenic activity in organ-cultured rabbit mammary gland and by its sodium-retaining activity in $F$. heteroclitus.

The first purification procedure adapted from Idler et al. (1978) and $\mathrm{Ng}$ et al. (1980) did not allow us to get purc chinook salmon prolactin. However, we obtained a preparation in which chinook salmon prolactin was the main protein as indicated by elec- 


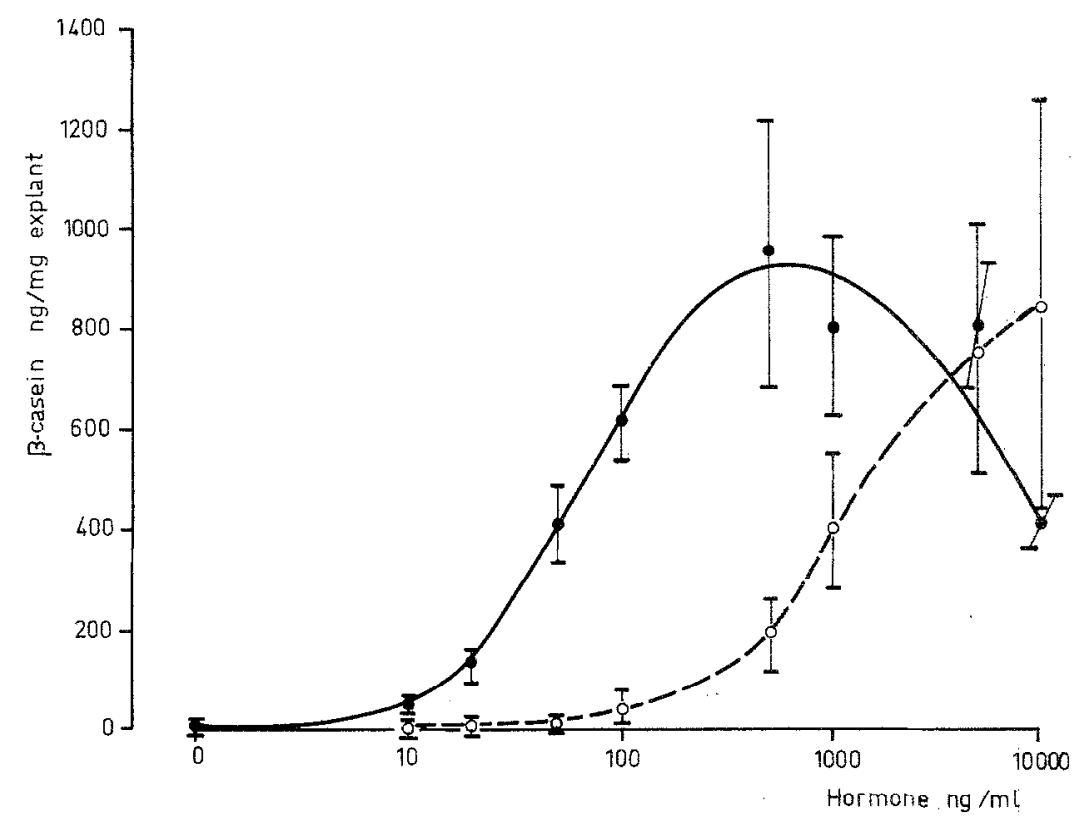

FIG. 4. Induction of $\beta$-casein accumulation in rabbit mammary explants by ovine and salmon prolactin. In all cases insulin was present at the concentration of $5 \mu \mathrm{g} / \mathrm{ml}$. The concentration of $\beta$-casein estimated by a radioimmunoassay is expressed in nanograms of $\beta$-casein per milligram of mammary explant. Each determination is the mean of three measurements.

trophoresis and radioreceptor assay results.

The second protocol seems particularly appropriate since only a few purification steps led to a highly purified hormone. One drawback remains the low yield of the final product $(70 \mathrm{mg} / \mathrm{kg})$. This is much lower than the yield obtained by Kawauchi et al. (1983) with chum prolactin $(1 \mathrm{~g} / \mathrm{kg})$. This discrepancy could be explained by differences in osmoregulation physiology between these two species (Hoar, 1976; Weisbart, 1968). However, the development of another chromatofocusing system better adapted to a very basic $\mathrm{pH}$ is presently being developed in our laboratory, in order to hopefully obtain a better recovery of prolactin.

Chinook salmon prolactin appeared to be a basic protein according to the electrofocusing experiments, a property which is also shared by chum salmon prolactin (Idler, 1981; Kawauchi et al., 1983). This result is confirmed by the behavior of chi- nook salmon prolactin on a chromatofócusing gel equilibrated at a basic $\mathrm{pH}$ and in electrophoresis performed at alkaline $\mathrm{pH}$; the absence of a stained band in this last technique is not associated with possible staining problem (Farmer et al., 1977), as this prolactin band can be clearly stained in the same electrophoresis system when polarity is reversed $\left(R_{f}<0.1\right)$.

The comparison between chinook salmon prolactin and chum salmon prolactin purified by Dr. H. Kawauchi shows that these two prolactins have similar or nearly identical biochemical characteristics. They run the same way in electrophoresis performed in presence of SDS, they are both basic proteins and their amino acid compositions are essentially in agreement (Kawauchi et al., 1983; see Table 2). This is not surprising if we consider the close phyllogenetic relationship between these two salmon species. As Tilapia prolactin, chinook salmon prolactin has a molecular weight smaller than that of mammalian pro- 
lactin and possesses four half-cystine residues or two disulfide bridges. The similarity between these two fish prolactins is partially confirmed by the comparison of their amino acid compositions.

In electrophoresis carried out at $\mathrm{pH} 4.5$ chinook salmon prolactin migrated as a major band preceded by a less intense band, a picturc strikingly reminiscent of the results obtained by Farmer et al. (1977) with tilapia prolactin. If we consider $\mathrm{NH}_{2}-$ terminal amino acid analysis and electrophoresis in presence of SDS as stringent criteria of purity, it seems unlikely that this less intensively stained band is a contaminant. The polymorphism revealed by electrophoresis and frequently observed with prolactin leads us to assume that this band is a deamidated form or a polymer (Shoer et al., 1978; Wallis et al., 1980; Nyberg et al., 1980; Proudman and Corcoran, 1981). If fish prolactin behaves like mammalian prolactin, our purification conditions (basic $\mathrm{pH}$, lyophilization) should favor the generation of this polymorphism (Lewis et al., 1970).

The lactogenic activity of chinook salmon prolactin, determined by its capacity to increase of casein synthesis in rabbit mammary gland explants is essentially similar to the activity of Tilapia prolactin (Houdebine et al., 1981). This result indicates that fish prolactins are endowed with significant lactogenic activity in the rabbit.

It is noteworthy that in the Fundulus bioassay pure chinook salmon prolactin was approximately 100 times more potent than ovine prolactin. An opposite ratio of bioactivity was observed for these two hormones in the radioreceptor assay, ovine prolactin being about 100 times more potent than chinook salmon prolactin.

Given that the chinook salmon prolactin and tilapia prolactin exhibit both osmoregulatory activity in fish and lactogenic activity in the rabbit, it seems legitimate to use routinely the radioreceptor assay estab- lished with rabbit mammary gland receptors as a bioindicator for fish prolactins, and to quantify the bioactivity of the preparation with the Fundulus bioassay.

\section{ACKNOWLEDGMENTS}

We are grateful to Dr. E. G. Grau, R. S. Niskioka, and S. Steiny for their help and to Professor H. A. Bern for his helpful support. We wish to thank Professor $\mathrm{H}$. Papkoff who performed amino acid and Nterminal amino acid analyses and Dr. Kawauchi who provided us helpful advice. We also thank Dr. J. Djiane who performed the radioimmunoassay of $\beta$-casein in collaboration with I. Dusanter and Dr. P. Martin who set up the electrofocusing experiments. This work was supported by NSF Grant PCM 81-10111 to Professor H. A. Bern, by a grant from the French Foreign Office for a stay in Berkeley to Dr. P. Prunet and was partially supported in France by the CNEXO.

\section{REFERENCES}

Clarke, W. C., and Bern, H. A. (1980). Comparative endocrinology of prolactin. In "Hormonal Proteins and Peptides" (C. H. Li, ed.), Vol. 8, pp. 105-177. Academic Press, New York.

Cole, R. D., and Li, C. H. (1955). Studies on pituitary lactogenic hormone. J. Biol. Chem. 213, 179-201.

Doneen, B. A. (1976). Biological activities of mammalian and teleostean prolactins and growth hormones on mouse mammary gland and teleost urinary bladder. Gen. Comp. Endocrinol. 30, 34-42.

Djiane, J., Houdebine, L. M., and Kelly, P. A. (1982). Correlation between prolactin receptor interaction, down-regulation of receptors and stimulation of casein and deoxyribonucleic acid biosynthesis in rabbit mammary explants. Endocrinology 110(3); 791-795.

Ensor, D. M. (1978). "Comparative Endocrinology of Prolactin." Chapman \& Hall, London.

Farmer, S. W., Papkufr, H., Bewley, T. A., Hayashida, T., Nishioka, R. S., Bern; H. A., and Li, C. H. (1977). Isolation and properties of teleost prolactin. Gen. Comp. Endocrinol. 31, G0-71.

Grau, E. G., Prunet, P., Nishioka, R. S., Gross, T., and Bern, H. A. (1984). Bioassay for salmon prolactin using hypophysectomized Fundulus heteroclitus. Gen. Comp. Endocrinol. 53, 78-85.

Gray, W. R. (1967). Sequential degradation plus dansylation. In "Methods Enzymology" (C. H. W. Hirs, Ed.), Vol. 11, 469-475. Academic Press, New York.

Hoar, W. S. (1976). Smolt transformation: Evolution, behavior and physiology. J. Fish. Res. Board Canad. 33, 1233-1252.

Houdebine, L. M., Farmer, S. W., and Prunet, P. (1981). Induction of rabbit casein synthesis in 
organ culture by tilapia prolactin and growth hormone. Gen. Comp. Endocrinol. 45, 61-65.

Idler, D. R. (1981): Salmon prolactin and its radioimmunoassay. In "ORI Symposium on Fish Migration and Reproduction." Ocean Research Institute, University of Tokyo, December 1-2, 1981.

Idler, D. R., Shamsuzzaman, K. M., and Burton, M. P. (1978). Isolation of prolactin from salmon pituitary. Gen. Comp. Endocrinol. 35, 409-418.

Kawauchi, H., Abe, K., Takahashi, A, Hirano, T., Hasegawa, S., Naito, N., and Nakai, Y. (1983). Isolation and properties of chum salmon prolactin. Gen. Comp. Endocrinol., 49, 446-458.

Kawauchi, H., and Tubokawa, M. (1979). Isolation and characterization of fin whale prolactin. Intl. J. Pept. Protein Res. 13, 229-234.

Lewis, U. J., Cheever, E. V., and Hopkins, W. C. (1970). Kinetic study of the deamidation of growth hormone and prolactin. Biochim. Biophys. Acta 214, 498-508.

Maurer, H. R. (1968). "Disc Electrophoresis and Related Techniques of Polyacrylamide Gel Electrophoresis." De Gruyter, Hawthorne, N. Y.

Ng, T. B., Idler, D. R., and Burton, M. P. (1980). A comparison of prolactins from a marine, an esluarine and a freshwater teleost. Gen. Comp. Endocrinol. 42, $141-146$.

Nicoll, C. S., and Bern; H. A. (1968). Further analysis of the occurrence of pigeon crop sac-stimulating activity (prolactin) in the vertebrate adenohypophysis. Gen. Comp. Endocrinol. 11, 5-20.

Nicoll, C. S., Bern, II. A., and Brown, D. (1966). Occurrence of mammotrophic activity (prolactin) in the vertebrate adenohypophysis. $J$. Endocrinol. $34,343-354$.

Nyberg, F., Roos, P., and Wide, L. (1980). Human pituitary prolactin. Isolation and characterization of three isohormones with different bioassay and radioimmunoassay activities. Biochim. Biophys. Acta 625, 255-265.

Proudman, J, A and Corcoran, D. H. (1981). Turkey prolactin: Purification by isotachophoresis and partial characterization. Biol. Reprod. 25, 375384.
Prunet, P., Djiane, J., and Breton, B. (1977). Application of a radioreceptor assay for lactogendic activity to the detection of fish prolactin-like hormone. J. Endocrinol. 73, 391-392.

Prunet, P., Houdebine, L. M., Delouis, C., and Breton, B. (1979). Stimulation of milk synthesis in the rabbit by fish pituitary extract. $J$. Endocrinol. $83,393-400$.

Prunet, P. (1981). "Contribution à la purification et à la caractérisation de la prolactine de Saumon, Oncorhynchus tschawytscha." Thèse de docteur, ingénieur, Institut National Agronomique ParisGrignon, Paris.

Riesfeld, R. A., Lewis, U. J., and Williams, D. E. (1962). Disc electrophoresis of basic proteins and peptides on polyacrylamide gels. Nature (London) 195, 281-283.

Shoer, L. F, Shine, N. R., and Talamantes, F. (1978). Isolation and partial characterization of secreted mouse pituitary prolactin. Biochim. Biophys. Acta 537, 336-347.

Shiu, R. P., Kelly, P. A., and Friesen, H. G. (1973). Radioreceptor assay for prolactin and other lactogenic hormones. Science 180, 968-970.

Spackman, D. H., Stein, W. H., and Moore, S. (1958). Automatic recording apparatus for use in the chromatography of aminoacids. Anal. Chem. 30; $1190-1206$.

Testud, M.; and Ribadeau-Dumas, B. (1973). Erude des caséines du lait de lapin. Biochimie 55, $1085-$ 1093.

Wallis, M., Daniels M., and Ellis, S. A. (1980). Size heterogeneity of rat pituitary prolactin. Biochem. $J .189,605-614$.

Weber, K., and Osborn, M. (1969). The reliability of molecular weight determinations by dodecylsulphate-polyacrylamide gel electrophoresis. $J$. Biochem. Chem. 244, 4406-4412.

Weisbart, M. (1968). Osmotic and ionic regulation in embryos, alevins and fry of the five species of Pacific salimon. Canad. J. Zool. 46, 385-397.

Woods, K. R., and Wang, K. T. (1967). Separrition of dansyl-amino acids by polyamide layer chromatography. Biochim. Biophys. Acta 133, 369-370. 